IdeAs

Idées d'Amériques

13 | 2019

La photographie documentaire contemporaine dans les Amériques

\title{
Contemporary documentary photography in the Americas
}

\section{Marion Gautreau and Jean Kempf}

Translator. Michael Hinchliffe

\section{OpenEdition}

\section{Journals}

\section{Electronic version}

URL: http://journals.openedition.org/ideas/5542

DOI: 10.4000/ideas.5542

ISSN: 1950-5701

\section{Publisher}

Institut des Amériques

Electronic reference

Marion Gautreau and Jean Kempf, "Contemporary documentary photography in the Americas », IdeAs [Online], 13 | 2019, Online since 01 March 2019, connection on 23 September 2020. URL : http:// journals.openedition.org/ideas/5542 ; DOI : https://doi.org/10.4000/ideas.5542

This text was automatically generated on 23 September 2020

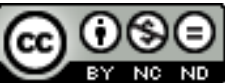

IdeAs - Idées d'Amériques est mis à disposition selon les termes de la licence Creative Commons Attribution - Pas d'Utilisation Commerciale - Pas de Modification 4.0 International. 


\title{
Contemporary documentary photography in the Americas
}

\author{
Marion Gautreau and Jean Kempf \\ Translation : Michael Hinchliffe
}

1 It is a commonplace, but one worth restating, that the nature of the relationship between photography and the real world has a specificity arising from the way in which the image is produced. From an early date, this specificity conferred on photography its role as a tool for the discovery and knowledge of the real world. What came little by little to be known as "documentary photography" (it is generally agreed that the term arose at some point in the 1920s) is rooted in the mode particular to the photographic image. Photography functions here not as a means of expression but as a means of exploration. But, straightforward as it appears, this opposition is more didactic than effective: there is no neat divide between these two types. However, whereas there are multiple ways photography can be used for its links with "reality", for instance, family snaps, identity photos, scientific, press, or forensic photography, documentary photography is something other. Though it is close to photo-reporting or indeed press photography in general by virtue of both theme and, on occasion, plastic form, it remains distinct from them. Documentary photography can be defined neither by style, as suggested in his historic contribution by Olivier Lugon (Lugon O., 2001), nor by its subject, that which is, as Stuart Franklin has written (Franklin S., 2016: 9), extraordinary. Its characteristics are, on the one hand, a discourse, an intention, a positioning on the part of the author and, on the other hand, a relationship between photographer and subject that involves a time-scale (however variable that scale may be, from several days to several years or even decades). Both these aspects imply particular attention as to how the documentary is to be published: a choice of form appropriate to complex narrative and extreme vigilance on the part of the photographer with regard to the use made of the production. This array of constraints amounts to what might be termed "pre-requisite demands".

2 In the introduction to her most recent book, Rebecca Monroy Nasr, historian of Mexican photography for over thirty years and photographer herself at the outset, 
suggests a differentiation between photo-reporting and documentary photography, activities that share the same informative purpose but diverge greatly in terms of their production and use:

The difference between documentary photography and photo-reporting comes into play with the social use to which the image is put and the intention with which the photographer takes it. We considered ourselves documentary photographers in as much as we captured subjects on film with no certainty of selling or publishing the material. Our motive was to bear witness to a given moment, even if our work remained dormant in our personal archives; our hope was that the possibility of publishing, exhibiting or compiling our photographs in a public manner would arise at some later date (Monroy Nasr R., 2017:21) ${ }^{1}$

3 From the large scale photographic enterprises which documented the surveys carried out during the $19^{\text {th }}$ century on the Western frontier to the urban investigations into bad housing, immigration and child labor at the turn of the century (e.g. in the work of Jacob Riis and Lewis Hine), or to the images of the Farm Security Administration in the 1930s, documentary practice had a long lineage when, in the 1920s, but especially from 1930 to 1960, it was taken up and used by the illustrated press under the form of "photo essays", called fotoensayos in Spanish (Chouard G. et al., 2014). This term (in French "essai photographique", though the expression is little used) signals the adoption of the codes of the literary essay: a structured reflection dealing with a clearly delimited subject, aimed at increasing awareness and possibly engaging debate. In this perspective, certain photo-reporters adopted a "double camera" approach (in Spanish " doble cámara"). Camera one is used for pictures to be published in newspapers or on internet news sites and its images are intended to show as fully as possible the information content of a situation. Camera two is used for images to be placed in photographic series, envisioned as such and carried out over a long term period. A case in point is that of the Mexican photo-reporter Fernando Brito in the State of Sinaloa, whose documentary work denounces the violence perpetrated in drug wars and develops the kind of social consciousness intrinsically linked to documentary photography.

4 Hence, even though US models have clearly dominated photography, and not only art or plastic photography, since at least the end of World War 2, specific visual cultures, local in nature, persist even in the present period of globalized images, producing particular forms of visual narrative. The difficulty, and indeed the worthwhileness, of envisaging documentary photography from the standpoint of the American continent as a whole arise from the different time scales involved in the development of the practice according to region. A further factor is that since the history of photography has been written and published in and from Europe and the US, exhuming the history of documentary photography in Latin American countries is akin to archeological research. There are few historical accounts to describe the genealogy of Chilean or Brazilian documentaries, even though, notwithstanding the absence of trace, the lineage exists, whereas for North America, since Beaumont Newhall's 1938 article at the very least, followed by the first edition of his history of photography (1949), the genre is identified, described, codified and, in part, given frame and norm².

5 Furthermore, there is no a priori convergence between the different phases of documentary photography in North and South America, any more than there is in Southern diversity. Although technical developments spread similarly throughout the Americas (e.g. the appearance of half-toning, the generalization of roll film, the 
introduction of color, the switch to digital), the driving force behind documentary photography resulting from institutions, political and social context or from the sheer possibility of production, differed substantially from country to country. The Southern Cone dictatorships of the 70s and 80s evinced a crying need for photographic essays in a period of repression, together with the material, physical impossibility of actually producing any ${ }^{3}$. At the very same period in Mexico, however, there arose an intense documentary activity, rooted in photo-reporting, particularly in Unomásuno et $L a$ Jornada, the authors of which gradually moved away from reporting towards the long term.

6 This why we have asked specialists of photography and American cultures to direct their attention to specific documentary practices in order to illustrate a wealth of diversity and complexity rather than convergence.

7 This issue on a selection of documentary practices in the Americas (exhaustiveness obviously would be impossible) is nevertheless organized around three modes to be found in varying degrees in a large number of documentary projects: scientific, or conversely, ideological reference; artistic form as an access to the complexities of the real world; the documentary as enabling an affirmation of identity or the retrieval of memory.

8 Combining as they do observation over a long period and narrative, documentaries naturally make abundant use of series, more or less strictly formalized but having the common effect of dilating temporality so as to capture its significance in processes of transformation. A case in point is the meticulous inventory conducted by Camilo José Vergara, a Chilean photographer working in the US where he has compiled a methodical urban archive of black ghettos which Philippe Bazin, himself a photographer, sees as a deleuzian war-machine, "a means of freeing [the ghetto] from the straight-jacket into which violent ultra-liberalism has forced it for decades".

9 Equally committed socially, but diametrically opposed as to form, the images made by Swiss photographer Jean-Claude Wicky between 1984 and 2001 in mines in Bolivia are an example both of classic humanist photography reminiscent, with their bodies rendered in rich black and white, of the work of W. Eugene Smith, and of participative observation. Describing the work of Wicky, little known in France, Baptiste Lavat shows us an experience which is that of many documentary photographers of everyday life, a sharing in lives that no longer fully belong to their subjects while still being theirs to live: a difficult half-way situation with which ethnographers and even sociologists are familiar.

10 A sharp contrast awaits the reader following the table-of-content order of the articles on discovering first what Danièle Méaux calls the spectacle of catastrophe in the images by Yves Marchand and Romain Meffre representing the "ruins of Detroit" followed by the sophisticated, ambiguous work from Joel Sternfield on New York's High Line walkway. The vestigial remains of a powerful industrial past have given rise to a present-day craze for what Danièle Méaux describes very nicely as "the decrepit neopicturesque" exploited by a post-modern tendency in photography. Despite producing images that stimulate an imagination of place and posit "a landscape in the making" Joel Sternfeld, as he documents the changing topography of an industrial past, participates in the up-market re-appropriation by privileged social classes of areas once devolved to production and now to leisure. 
11 The difficulty in giving expression to the brutality and exclusion generated by modern cities, and, more generally, to the real "tout court" (in its harshest aspect) is discussed by Gwen Cressman, who choses for the purpose a comparison between two highly different photographic oeuvres, respectively those of Martha Rosler and Jeff Wall, who nevertheless share the same distrust as to the possibility of any simple, direct access to the real world via photography. The plastic, conceptual images of both these photographers constantly interrogate both the desire to see and the resistance of the world to the effort of comprehension.

12 Addressing more concrete matters, the third part of this issue deals with three different trajectories which combine an account of one or more social, cultural or historical situations with an attempt to deconstruct stereotypes not only by means of making images, but also by an integration into other discursive groupings or specific entities. Morgana Herrera discusses the work of Musuk Nolte, a Peruvian photographer who uses back and white series to counteract exotic representations of Amazonia. By his choice of subject (more urban than rural) and his treatment of the people he photographs (engaged in their everyday lives subject to the duress of their living conditions), he provides a non-ethnographic place for these inhabitants of Peruvian Amazonia on the international visual stage. In her article, Maude Oswald shows how an inventory of functional signs (civil defense markings on buildings abandoned after hurricane Katrina) becomes, when published on the web, a means for after-the-fact memory building whereby the photographs exercise retroactively a re-appropriative force on the real world event. Re-appropriation is central to the project studied by Aurélie Journée in which an indigenous American woman photographer produces portraits that attempt to combine ancestral heritage with a modern approach more conducive to fuller expression, particularly on the part of native American women.

Although of necessity a partial one, the approach offered here is nevertheless able to register subtle differences within a preoccupation that runs through documentary photography: the idea of emancipation.

\section{BIBLIOGRAPHY}

Chouard, Géraldine, Kempf, Jean et Brunet, François, « La photographie "documentaire” américaine : nouvelles approches », Transatlantica, vol. 2, 2014, http://journals.openedition.org/ transatlantica/7245, page consultée le 23 février 2019.

Franklin, Stuart, The Documentary Impulse, Londres, Phaidon, 2016.

Lugon, Olivier, Le style documentaire : d'August Sander à Walker Evans, 1920-1945, Paris, Macula, 2001. Meiselas, Susan (dir.), Chile from within, New York ; Londres, W.W. Norton \& Company, 1990.

Monroy Nasr, Rebeca, Con el deseo en la piel. Un episodio de la fotografía documental a fines del siglo xx, Mexico, UAM-Xochimilco, 2017. 
Newhall, Beaumont, « Documentary Approach to Photography », Parnassus, vol. 10, n 3, 1938, p. 2-6 [accessible sur JSTOR, http://www.jstor.org/stable/771747].

Newhall, Beaumont, The History of Photography from 1839 to the Present Day, New York, Museum of Modern Art, 1949. Traduction française en 1967.

\section{NOTES}

1. «La diferencia entre fotodocumentalismo y fotoperiodismo se establece a partir del uso social de la imagen y la intención con la que el fotógrafo toma esta imagen. Nos considerábamos fotógrafos documentales aquellos que captábamos el acontecimiento sin tener la certeza clara de la venta o la publicación del material. Trabajábamos con el deseo de dejar un testimonio visual del momento aunque éste solo se integrara a nuestro acervo personal, con la posibilidad de publicar posteriormente para realizar alguna exposición o edición de las imágenes en algún espacio público. »

2. However, the work of certain Latin American historians of photography currently engaged in gradually reconstructing the missing narratives should be mentioned, for example, cora Gamarnik in Argentina, Boris Kossoy and Ana María Mauad in Brazil, Rebecca Monroy Nasr, John Mraz or Alberto del Castillo in Mexico, to name but a few.

3. On this subject, see Meiselas S., 1990.

\section{AUTHORS}

\section{MARION GAUTREAU}

Enseignante-chercheuse au département d'études hispaniques et hispano-américaines de l'Université Toulouse-Jean Jaurès. Historienne de la photographie latino-américaine, elle est notamment spécialiste du Mexique. Ses recherches portent essentiellement sur la photographie de presse et la photographie documentaire dans leur articulation avec le récit historique national, aux $\mathrm{xx}^{\mathrm{e}}$ et $\mathrm{xxI}^{\mathrm{e}}$ siècles. Elle a publié un ouvrage sur la photographie de la Révolution mexicaine, De la crónica al ícono: la fotografía de la Revolución Mexicana en la prensa ilustrada capitalina (1910-1940), et travaille actuellement sur le photojournalisme mexicain depuis 1968.

\section{JEAN KEMPF}

Professeur de civilisation des États-Unis à l'Université Lumière-Lyon 2. Il est spécialiste de l'histoire de la photographie américaine au $\mathrm{xx}^{\mathrm{e}}$ siècle. Il a notamment écrit sur la commande institutionnelle, sur les street photographers et sur les pratiques documentaires, et s'intéresse aujourd'hui à la sociologie des milieux photographiques contemporains. Il a participé à l'aventure de L'Amérique des images (Hazan, 2013) et a publié une Histoire culturelle des États-Unis (Belin, 2015). 